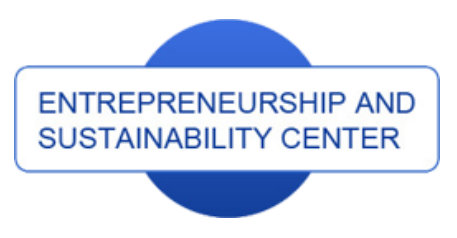

Publisher

$\underline{\text { http://jssidoi.org/esc/home }}$

\title{
NEW INFORMATION TECHNOLOGIES USE FOR LATVIAN COMPANIES FINANCIAL HEALTH EVALUATION
}

\author{
Sergejs Hilkevics ${ }^{1}$, Galina Hilkevica ${ }^{2}$ \\ ${ }^{1,2}$ Ventspils University College, 101a Inzenieru Street, LV-3601, Ventspils, Latvia \\ E-mails: ${ }^{1}$ sergejs.hilkevics@venta.lv; ${ }^{2}$ galina.hilkevica@venta.lv
}

Received 20 August 2017; accepted 15 November; published 29 December 2017.

\begin{abstract}
Financial health of companies in certain region is the foundation on which the prosperity of region is based. If companies in region are healthy and successful, there are good reasons to believe that all social problems can be solved relatively easy. Regional economic development in Latvia at present time happens inhomogeniously - there is a growing region near Riga where economic and social development is going very good, and there are regions where results are worse. The main purpose of this paper is to describe, apply and provide critical review the existing information technologies based possibilities for Latvian companies' financial health evaluation. We focus on the set of financial ratios necessary for economic health evaluation and homepages parsing based methods for these ratios determination for Latvian companies.
\end{abstract}

Keywords: new information technologies, fundamental analysis

Reference to this paper should be made as follows: Hilkevics, S.; Hilkevica, G. 2017. New Information Technologies Use for Latvian Stock Companies Financial Health Evaluation, Entrepreneurship and Sustainability Issues 5(2): 178-189 $\underline{\text { http://doi.org/10.9770/jesi.2017.5.2(1) }}$

JEL Classifications: M2, M4

\section{Introduction}

The main purpose of this paper is to describe the information technologies based possibilities for Latvian companies' financial health evaluation. There are two steps in company financial health evaluation. The first step is the de-termination of the set of financial ratios used for evaluation and the second step is the ratios comparison with optimal values.

There are several approaches for the set of financial ratios determination. The common feature for all these approaches is that all of them are based on the same groups of financial ratios - profitability, operating efficiency, solvency and liquidity. The differences are related with the amount of considered ratios, from 7-8 in simple cases up to 20-30 in complicated ones, and with the degree of detalization of consideration. Differences in approaches for company financial health evaluation are related with the goals of evaluation also - usually in theoretical studies and in practical applications sets of financial ratios are slightly different (Belás et al. 2017; Paseková et al. 2017). 
The classical theoretical approach in assessing the financial health of the firm is de-scribed in Analysis for Financial Management (Higgins, 2012). According to this approach main three financial statements of company cash flow, balance sheet and income statement - are considered at first to receive "a set of objective numbers, that provide information about the firm's performance, problems, and prospects" (Higgins, 2012). After that the following profitability, turnover-control, liquidity, leverage ratios are considered their sense for company financial health evaluation is analysed (Table 1):

Table 1. Profitability ratios

\begin{tabular}{|l|l|}
\hline Profitability Ratios & $=$ Net income/Shareholders' equity \\
\hline Return on equity & $=$ Net income/Assets \\
\hline Return on assets & $\begin{array}{l}=\text { (Earnings before interest and taxes) } *(1-\text { Tax rate }) /(\text { Interest-bearing } \\
\text { debt }+ \text { Shareholders' equity })\end{array}$ \\
\hline Return on invested capital & $=$ Net income/Sales \\
\hline Profit margin & $=$ Gross profit/Sales \\
\hline Gross margin & $=$ Price per share/Earnings per share \\
\hline Price to earnings &
\end{tabular}

Profitability ratios is the first group of ratios for financial health evaluation and they form the foundation on which all the further evaluation of financial health of company is based. Strategic management theory considers (Hill, Jones, 2013) that the long term profit higher than average in industry is the decisive factor of company competitiveness.

Table 2. Turnover-Control Ratios

\begin{tabular}{|c|c|}
\hline \multicolumn{2}{|c|}{ Turnover-Control Ratios } \\
\hline Asset turnover & $=$ Sales $/$ Assets \\
\hline Fixed-asset turnover & $=$ Sales/Net property, plant, and equipment \\
\hline Inventory turnover & $=$ Cost of goods sold/Ending inventory \\
\hline Collection period & $\begin{array}{l}=\text { Accounts receivable/Credit sales per day (If credit sales unavailable, use } \\
\text { sales) }\end{array}$ \\
\hline Days' sales in cash & $=$ Cash and securities/Sales per day \\
\hline Payables period & $=$ Accounts payable/Credit purchases per day \\
\hline
\end{tabular}

Turnover-control ratios (Table 2) is the second group of ratios for financial health evaluation and also should be considered in time perspective - dynamics of sales is often considered as the second important factor after profit for company health evaluation. The positive correlation between sales growth and profit growth is the indicator of the good financial health of company. Unfortunately, for Latvian companies in several cases sales growth is observed simultaneously with profit decreasing which means the existence of certain difficulties in development. Liquidity ratios (Table 3 ) is the third group of ratios for financial health evaluation and is very important for the evaluation of company ability to cover short-term liabilities. There is opinion that financial health by the origin is the long-term ability to pay in time short-term debts.

Table 3. Leverage and Liquidity Ratios

\section{Leverage and Liquidity Ratios}

Assets to equity

Debt to assets
$=$ Assets/Shareholders' equity

$=$ Total liabilities/Assets (Interest-bearing debt is often substituted for total liabilities) 
ENTREPRENEURSHIP AND SUSTAINABILITY ISSUES

ISSN 2345-0282 (online) http://jssidoi.org/jesi/

2017 Volume 5 Number 2 (December)

http://doi.org/10.9770/jesi.2017.5.2(1)

\begin{tabular}{|c|c|}
\hline \multicolumn{2}{|c|}{ Leverage and Liquidity Ratios } \\
\hline Debt to equity & $=$ Total liabilities/Shareholders' equity \\
\hline Times interest earned & $=$ Earnings before interest and taxes/Interest expense \\
\hline Times burden covered & $=$ EBIT/( Interest exp. + Prin. pay. $) *(1-$ Tax rate $)$ \\
\hline Debt to assets & Total liabilities / Assets \\
\hline Debt to equity & $=($ Total liabilities $) /($ Capitalization + Total liabilities $)$ \\
\hline Current ratio & $=$ Current assets/Current liabilities \\
\hline Quick ratio & $=($ Current assets - Inventory $) /$ Current liabilities \\
\hline
\end{tabular}

The considered set of financial ratios is the typical example of so called theoretically oriented approach. As the typical sample of practically oriented approach for financial health evaluation let us consider the "20 Balance Sheet Ratios to Measure a Company's Health" suggested by www.oldschoolvalue.com (Table 4):

Table 4. 20 Balance Sheet Ratios to Measure a Company's Health, source: www.oldschoolvalue.com

\begin{tabular}{|l|l|}
\hline Solvency & $=$ (Current Assets - Inventories) / Current Liabilities \\
\hline Quick Ratio & $=$ Current Assets / Current Liabilities \\
\hline Total Debt/Equity Ratio & $=$ Total Liabilities / Shareholders Equity \\
\hline Long Term Debt/Equity Ratio & $=$ Long Term Debt / Shareholders Equity \\
\hline Short Term Debt/Equity Ratio & $=$ Short Term Debt / Shareholders Equity \\
\hline
\end{tabular}

\begin{tabular}{|c|c|}
\hline \multicolumn{2}{|l|}{ Liquidity Ratios } \\
\hline Days Sales Outstanding & $=($ Receivables / Revenue $) \times 365$ \\
\hline Days Inventory Outstanding & $=($ Inventory / COGS $) \times 365$ \\
\hline Days Payable Outstanding & $=($ Accounts Payable $/$ COGS $) \times 365$ \\
\hline Cash Conversion Cycle & $=\mathrm{DSO}+\mathrm{DIO}-\mathrm{DPO}$ \\
\hline Receivables Turnover & = Revenue / (Average of Current and Prior Year Receivables) \\
\hline Inventory Turnover & $=$ COGS / (Average of Current and Prior Year Inventory) \\
\hline Average Age of Inventory (Days) & $=365 /$ Inventory Turnover \\
\hline Intangibles \% of Book Value & $=$ Intangibles / Shareholders Equity \\
\hline Inventory \% of Revenue & = Inventory / Revenue \\
\hline
\end{tabular}

\begin{tabular}{|l|l|}
\hline \multicolumn{2}{|l|}{ Capital Structure Ratios } \\
\hline LT-Debt as \% of Invested Capital & $=$ Long Term Debt / Invested Capital \\
\hline ST-Debt as \% of Invested Capital & $=$ Short Term Debt / Invested Capital \\
\hline LT-Debt as \% of Total Debt & $=$ Long Term Debt / Total Liabilities \\
\hline ST-Debt as \% of Total Debt & $=$ Short Term Debt / Total Liabilities \\
\hline Total Liabilities \% of Total Assets & $=$ Total Liabilities / Total Assets \\
\hline Working Capital \% of Price & $=$ Working Capital / Market Cap \\
\hline
\end{tabular}

Comparing ratios of two company financial health evaluation approaches, we can see that they use very similar sets of ratios, but practically oriented system pays more attention to capital structure. Approximately the same sets of financial ratios use other practical oriented approaches for company financial health evaluation.

The second step in financial health of company evaluation after the set of financial ratios determination is the financial ratios comparison with optimal values. In several cases such comparison can be performed relatively easy - for example, for all profitability ratios the recommendation of strategic management theory is that in long term perspective profit should be higher, that average profit in industry. If the average profit in industry is known from statistical data - sometimes this is so and later we will consider such cases - it is not difficult to compare company data with statistical data and make conclusions about company competitiveness and financial health. 
However, in many cases the determination of optimal values of financial ratios is not so simple and it is necessary to consider which financial information is available and which is not.

\section{Information sources and data processing}

Speaking about world level sources of companies financial reports it necessary to mention US SEC information system EDGAR at first. There are more than 21 million docu-ments with financial reports of many thousands American stock companies since 1934 in free access there. The serious advantage of EDGAR system comparing with similar European in-formation systems is the use of XBRL standard in financial documents, which makes the au-tomatization of information processing possible. In Europe XBRL is supposed to become a standard for financial reports for stock companies since January 1, 2020. As result, researches have serious differences in possibilities to study American and European companies - for American stock companies it is possible, for example, to download from http://www.nasdaq.com/screening/company-list.aspx the list of NASDAQ, NYSE and AMEX traded stocks lists, to receive free of charge for all these companies from EDGAR forms 10-K and 10-Q with year and quarter financial reports, containing balance sheets, cash flows and income statements for last 10 years in XML format, using GAAP taxonomy extract from XML documents above mentioned ratios for company financial health evaluation and compare them with average for industry values. These average values can be calculated for industry since we know appropriate data for all stock companies in industry.

Situation is more complicated in Europe. From one side, we have stock exchanges in all European countries, we have access to data from national financial market regulators, Eu-ropean Securities and Market Authority and European Stock Exchanges also provide informa-tion about stock companies year and quarter reports. From another side, it is impossible to repeat for European companies the above described procedure which is possible for American companies. There is no analog of EDGAR in Europe, financial reports are available from Eu-ropean stock exchanges free of charge in pdf format only and it is much more difficult, but sometimes even impossible to organize automatic information receiving and processing for necessary financial ratios calculation. The only known to authors regular way to receive free of charge necessary information is to use methods similar to regular expression analysis. Let us consider at first the simple example of such approach use.

The server of the Register of Latvian companies http://dati.ur.gov.lv contains Latvian companies initial registration data. The manual about the rules of server use in Latvian can be found at http://dati.ur.gov.lv/ur_opendata.pdf and the list of 372590 Latvian companies can be found on the server with the data about company name, address, data of registration and registration code. More detailed information about Latvian companies can be found on the server http:Ilcompany.lursoft.lv of company Lursoft which in addition to Register data contains information about company activities according to NACE classificatory and tax payments. Data about company Lursoft itself can be found on server by two ways - or using the link http://company.lursoft.lv/lursoft with company name, or using the link with company code of registration http://company.lursoft.lv/40003053936. It is important, that if we know from the Register server only the names of 372590 Latvian companies, we cannot automatically receive data about them from Lursoft server - there is no direct relation between the link to data and the name of company. But if we know their registration codes also, the link to company data on Lursoft server can be generated automatically. By this way we can receive information necessary for example for regional studies - if from home pages parsing we know NACE code of company activity, address and taxes payed, we can analyze different sectors contributions in regional economies. By the similar way we have confirmed the existence of pronounced regional localization of ICT sector enterprises in Latvia. Out of the total 311.34 million taxes paid by ICT sector enterprises, 282.14 million, or 90.62\%, are paid in Riga. The effect of localization increases with the size of the enterprise that is the tendency to localize for large enterprises is expressed more noticeable than for a small business. If the share of enterprises with tax payments less than 2,500 euros per year is $68.86 \%$ in Riga, the share of enterprise with tax payments more than one million euros in Riga increases to $92 \%$. Such kind of results can be used for the strategy of regional economic development creation. 
The similar home pages and XML documents parsing for financial data receiving can be used in other cases also and as the second example of above described approach imple-mentation we will consider the Latvian stock companies financial health evaluation.

\section{Latvian stock companies financial health evaluation}

Riga Stock Exchange, now Nasdaq Riga, is owned mostly by Nasdaq OMX and together with Vilnius Stock Exchange and Tallinn Stock Exchange is a part of Nasdaq Baltic operating in Baltic countries. This is the reason why Riga Stock Exchange follows to Nasdaq OMX regulations and American company Morning Star on the base of contract with Nasdaq OMX converts Nasdaq Riga financial reports into XML format in the same way as this is done for American companies. By this way reports of such Latvian stock companies as GRD1R (Grindeks), HMX1R (HansaMatrix), LSC1R (Latvijas kuǵniecība), OLF1R (Olainfarm), SAF1R (SAF Tehnika), BRV1R (Brīvais Vilnis), LOK1R (Daugavpils Lokomotīvju Remonta Rūpnīca), DPK1R (Ditton pievadķěžu rūpnīca), GRZ1R (Grobiṇa), KA11R (Kurzemes atslēga 1), KCM1R (Kurzemes ciltslietu un mākslīgās apsēklošanas stacija), BAL1R (Latvijas balzams), GZE1R (Latvijas Gāze), LJM1R (Latvijas Jūras medicīnas centrs), SMA1R (PATA Saldus), RAR1R (Rīgas autoelektroaparātu rūpnīca), RER1R (Rīgas elektromašīnbūves rūpnīca), RJR1R (Rīgas juvelierizstrādājumu rūpnīca), RKB1R (Rīgas kuğu būvētava), SCM1R (Siguldas ciltslietu un mākslīgās apsēklošanas stacija), TKB1R (Tosmares kuğubūvētava), VSS1R (Valmieras stikla škiiedra), VEF1R (VEF), RRR1R (VEF Radiotehnika RRR) are available in XML format. This gives the possibility to evaluate the above described set of financial ratios necessary for company financial health evaluation. Let us consider as the example those ratios for stock company Grindex for last 5 years (Table 5).

Table 5. GRINDEX

\begin{tabular}{|c|c|c|c|c|c|}
\hline & 2012 & 2013 & 2014 & 2015 & 2016 \\
\hline Revenue & $100.00 \%$ & $100.00 \%$ & $100.00 \%$ & $100.00 \%$ & $100.00 \%$ \\
\hline Cost of Revenue & $38.24 \%$ & $39.99 \%$ & $45.73 \%$ & $55.75 \%$ & $45.35 \%$ \\
\hline Gross Margin & $61.76 \%$ & $60.01 \%$ & $54.27 \%$ & $44.25 \%$ & $54.65 \%$ \\
\hline Operating Margin & $14.86 \%$ & $13.75 \%$ & $-2.15 \%$ & $1.75 \%$ & $11.52 \%$ \\
\hline EBT Margin & $14.61 \%$ & $13.75 \%$ & $-2.15 \%$ & $1.75 \%$ & $11.52 \%$ \\
\hline Net Margin & $11.65 \%$ & $11.40 \%$ & $-2.87 \%$ & $1.25 \%$ & $9.03 \%$ \\
\hline Return on Assetsf & 10.06 & 9.29 & -1.63 & 0.65 & 5.73 \\
\hline Return on Equity & 13.7 & 11.94 & -2.23 & 0.95 & 8.32 \\
\hline Operating Cash Flow Growth YOY & 157.98 & 26.39 & -66.41 & -43.78 & -4.58 \\
\hline Cap Ex as a \% of Sales & $-3.41 \%$ & $-4.84 \%$ & $-4.13 \%$ & $-4.37 \%$ & $-5.10 \%$ \\
\hline Free Cash Flow/Sales & $8.21 \%$ & $9.75 \%$ & $2.43 \%$ & $-0.42 \%$ & $-2.15 \%$ \\
\hline Free Cash Flow/Net Income & 0.71 & 0.86 & -0.85 & -0.34 & -0.24 \\
\hline Total current assets & $52.60 \%$ & $49.05 \%$ & $49.49 \%$ & $50.25 \%$ & $55.37 \%$ \\
\hline Total current liabilities & $15.16 \%$ & $13.53 \%$ & $24.37 \%$ & $22.26 \%$ & $20.81 \%$ \\
\hline Total Liabilities & $23.86 \%$ & $20.64 \%$ & $32.32 \%$ & $30.53 \%$ & $31.77 \%$ \\
\hline Total stockholders' equity & $76.14 \%$ & $79.36 \%$ & $67.68 \%$ & $69.47 \%$ & $68.23 \%$ \\
\hline Liquidity/Financial Health - Current Ratio & 3.47 & 3.62 & 2.03 & 2.26 & 2.66 \\
\hline Liquidity/Financial Health - Quick Ratio & 2.86 & 2.84 & 1.41 & 1.49 & 1.75 \\
\hline $\begin{array}{l}\text { Liquidity/Financial Health - Financial } \\
\text { Leverage }\end{array}$ & 1.31 & 1.26 & 1.48 & 1.44 & 1.47 \\
\hline Cash Conversion Cycle & 187.15 & 184.08 & 247.43 & 280.27 & 305.24 \\
\hline
\end{tabular}


Grindex is one of the pharmaceutical leaders in Baltic countries and one of the best Latvian companies. Grindex Gross Margin, often considered as the foundation of financial health of company, on which other financial health indicators are based, is the third largest among Latvian Stock companies. Operating Margin, EBT Margin and Net Margin are high enough, Liquidity ratios are good enough also. Cash Flow indicators are problematic, buy it is necessary to take into account events around the one of Grindex products meldronium which was forbidden for use in sport. In general the financial health of Grindex can be evaluated as very good.

Situation with others Latvian companies in several cases is not so optimistic. Let us consider the shorted list of financial ratios for 24 Latvian stock companies (Table 6).

Table 6. Shorted list of financial ratios for 24 Latvian stock companies

\begin{tabular}{|c|c|c|c|c|c|c|}
\hline Name of stock company & Indicator & 2012 & 2013 & 2014 & 2015 & 2016 \\
\hline GRD1R & Revenue & $100.00 \%$ & $100.00 \%$ & $100.00 \%$ & $100.00 \%$ & $100.00 \%$ \\
\hline \multirow[t]{5}{*}{ Grindeks } & Cost of Revenue & $38.24 \%$ & $39.99 \%$ & $45.73 \%$ & $55.75 \%$ & $45.35 \%$ \\
\hline & Gross Margin & $61.76 \%$ & $60.01 \%$ & $54.27 \%$ & $44.25 \%$ & $54.65 \%$ \\
\hline & Operating Margin & $14.86 \%$ & $13.75 \%$ & $-2.15 \%$ & $1.75 \%$ & $11.52 \%$ \\
\hline & EBT Margin & $14.61 \%$ & $13.75 \%$ & $-2.15 \%$ & $1.75 \%$ & $11.52 \%$ \\
\hline & Net Margin & $11.65 \%$ & $11.40 \%$ & $-2.87 \%$ & $1.25 \%$ & $9.03 \%$ \\
\hline HMX1R & Revenue & $100.00 \%$ & $100.00 \%$ & $100.00 \%$ & $100.00 \%$ & $100.00 \%$ \\
\hline \multirow[t]{5}{*}{ HansaMatrix } & Cost of Revenue & $72.96 \%$ & $76.39 \%$ & $78.39 \%$ & $80.06 \%$ & $86.61 \%$ \\
\hline & Gross Margin & $27.04 \%$ & $23.61 \%$ & $21.61 \%$ & $19.94 \%$ & $13.39 \%$ \\
\hline & Operating Margin & $11.00 \%$ & $8.58 \%$ & $-17.38 \%$ & $11.13 \%$ & $4.62 \%$ \\
\hline & EBT Margin & $11.00 \%$ & $8.58 \%$ & $-17.38 \%$ & $9.33 \%$ & $3.38 \%$ \\
\hline & Net Margin & $10.17 \%$ & $7.55 \%$ & $-19.05 \%$ & $8.11 \%$ & $3.25 \%$ \\
\hline LSC1R & Revenue & $100.00 \%$ & $100.00 \%$ & $100.00 \%$ & $100.00 \%$ & $100.00 \%$ \\
\hline \multirow[t]{5}{*}{ Latvijas kuǵniecība } & Cost of Revenue & $79.46 \%$ & $69.54 \%$ & $69.27 \%$ & $64.18 \%$ & $85.10 \%$ \\
\hline & Gross Margin & $20.54 \%$ & $30.46 \%$ & $30.73 \%$ & $35.82 \%$ & $14.90 \%$ \\
\hline & Operating Margin & $-13.61 \%$ & $-2.47 \%$ & $-24.81 \%$ & $1.03 \%$ & $-14.99 \%$ \\
\hline & EBT Margin & $-29.81 \%$ & $-17.28 \%$ & $-33.77 \%$ & $-7.40 \%$ & $-26.55 \%$ \\
\hline & Net Margin & $-29.90 \%$ & $-17.38 \%$ & $-34.00 \%$ & $-7.50 \%$ & $-24.99 \%$ \\
\hline OLF1R & Revenue & $100.00 \%$ & $100.00 \%$ & $100.00 \%$ & $100.00 \%$ & $100.00 \%$ \\
\hline \multirow[t]{5}{*}{ Olainfarm } & Cost of Revenue & $21.63 \%$ & $21.73 \%$ & $31.69 \%$ & $33.18 \%$ & $36.91 \%$ \\
\hline & Gross Margin & $78.37 \%$ & $78.27 \%$ & $68.31 \%$ & $66.82 \%$ & $63.09 \%$ \\
\hline & Operating Margin & $22.26 \%$ & $19.09 \%$ & $14.78 \%$ & $18.12 \%$ & $13.21 \%$ \\
\hline & EBT Margin & $22.26 \%$ & $19.09 \%$ & $14.78 \%$ & $18.12 \%$ & $13.48 \%$ \\
\hline & Net Margin & $18.43 \%$ & $16.33 \%$ & $13.07 \%$ & $15.69 \%$ & $10.46 \%$ \\
\hline
\end{tabular}


The International Journal

ENTREPRENEURSHIP AND SUSTAINABILITY ISSUES

ISSN 2345-0282 (online) http://jssidoi.org/jesi/

2017 Volume 5 Number 2 (December)

http://doi.org/10.9770/jesi.2017.5.2(1)

\begin{tabular}{|c|c|c|c|c|c|c|}
\hline SAF1R & Revenue & $100.00 \%$ & $100.00 \%$ & $100.00 \%$ & $100.00 \%$ & $100.00 \%$ \\
\hline \multirow[t]{5}{*}{ SAF Tehnika } & Cost of Revenue & $55.93 \%$ & $76.77 \%$ & $77.10 \%$ & $69.96 \%$ & $67.26 \%$ \\
\hline & Gross Margin & $44.07 \%$ & $23.23 \%$ & $22.90 \%$ & $30.04 \%$ & $32.74 \%$ \\
\hline & Operating Margin & $6.18 \%$ & $-0.43 \%$ & $-0.21 \%$ & $6.11 \%$ & $4.61 \%$ \\
\hline & EBT Margin & $8.37 \%$ & $-0.05 \%$ & $1.19 \%$ & $11.54 \%$ & $7.26 \%$ \\
\hline & Net Margin & $7.47 \%$ & $-0.16 \%$ & $0.99 \%$ & $9.98 \%$ & $6.75 \%$ \\
\hline BRV1R & Revenue & $100.00 \%$ & $100.00 \%$ & $100.00 \%$ & $100.00 \%$ & $100.00 \%$ \\
\hline \multirow[t]{5}{*}{ Brīvais Vilnis } & Cost of Revenue & $86.57 \%$ & $87.04 \%$ & $88.26 \%$ & $89.67 \%$ & $93.01 \%$ \\
\hline & Gross Margin & $13.43 \%$ & $12.96 \%$ & $11.74 \%$ & $10.33 \%$ & $6.99 \%$ \\
\hline & Operating Margin & $8.15 \%$ & $5.35 \%$ & $2.56 \%$ & $-10.07 \%$ & $-12.24 \%$ \\
\hline & EBT Margin & $6.05 \%$ & $5.35 \%$ & $2.56 \%$ & $-10.07 \%$ & $-12.24 \%$ \\
\hline & Net Margin & $5.47 \%$ & $4.41 \%$ & $2.01 \%$ & $-10.56 \%$ & $-12.24 \%$ \\
\hline LOK1R & Revenue & $100.00 \%$ & $100.00 \%$ & $100.00 \%$ & $100.00 \%$ & $100.00 \%$ \\
\hline \multirow[t]{5}{*}{ Daugavpils Lokomotīvju Remonta Rūpnīca } & Cost of Revenue & $84.72 \%$ & $94.82 \%$ & $93.05 \%$ & $104.35 \%$ & $110.54 \%$ \\
\hline & Gross Margin & $15.28 \%$ & $5.18 \%$ & $6.95 \%$ & $-4.35 \%$ & $-10.54 \%$ \\
\hline & Operating Margin & $4.53 \%$ & $-0.73 \%$ & $-6.19 \%$ & $-13.72 \%$ & $-21.21 \%$ \\
\hline & EBT Margin & $4.26 \%$ & $-0.73 \%$ & $-6.19 \%$ & $-13.72 \%$ & $-21.21 \%$ \\
\hline & Net Margin & $3.30 \%$ & $-0.72 \%$ & $-6.20 \%$ & $-14.29 \%$ & $-16.81 \%$ \\
\hline DPK1R & Revenue & $100.00 \%$ & $100.00 \%$ & $100.00 \%$ & $100.00 \%$ & $100.00 \%$ \\
\hline \multirow[t]{5}{*}{ Ditton pievadķēžu rūpnīca } & Cost of Revenue & $80.10 \%$ & $90.26 \%$ & $86.80 \%$ & $126.65 \%$ & $98.75 \%$ \\
\hline & Gross Margin & $19.90 \%$ & $9.74 \%$ & $13.20 \%$ & $-26.65 \%$ & $1.25 \%$ \\
\hline & Operating Margin & $0.97 \%$ & $0.72 \%$ & $-55.75 \%$ & $-66.24 \%$ & $0.26 \%$ \\
\hline & EBT Margin & $0.04 \%$ & $0.72 \%$ & $-55.75 \%$ & $-66.24 \%$ & $0.26 \%$ \\
\hline & Net Margin & $0.03 \%$ & $0.04 \%$ & $-56.32 \%$ & $-67.20 \%$ & $0.26 \%$ \\
\hline GRZ1R & Revenue & $100.00 \%$ & $100.00 \%$ & $100.00 \%$ & $100.00 \%$ & $100.00 \%$ \\
\hline \multirow[t]{5}{*}{ Grobiṇa } & Cost of Revenue & $64.63 \%$ & $54.42 \%$ & $122.07 \%$ & $102.95 \%$ & $206.75 \%$ \\
\hline & Gross Margin & $35.37 \%$ & $45.58 \%$ & $-22.07 \%$ & $-2.95 \%$ & $-106.75 \%$ \\
\hline & Operating Margin & $23.86 \%$ & $30.65 \%$ & $-37.83 \%$ & $4.32 \%$ & $-129.14 \%$ \\
\hline & EBT Margin & $21.20 \%$ & $24.47 \%$ & $-54.58 \%$ & $4.32 \%$ & $-129.14 \%$ \\
\hline & Net Margin & $21.14 \%$ & $21.05 \%$ & $-57.56 \%$ & $15.56 \%$ & $-117.94 \%$ \\
\hline KA11R & Revenue & $100.00 \%$ & $100.00 \%$ & $100.00 \%$ & $100.00 \%$ & $100.00 \%$ \\
\hline \multirow[t]{2}{*}{ Kurzemes atslēga 1} & Cost of Revenue & $90.57 \%$ & $90.46 \%$ & $88.11 \%$ & $92.63 \%$ & $106.87 \%$ \\
\hline & Gross Margin & $9.43 \%$ & $9.54 \%$ & $11.89 \%$ & $7.37 \%$ & $-6.87 \%$ \\
\hline
\end{tabular}


The International Journal

ENTREPRENEURSHIP AND SUSTAINABILITY ISSUES

ISSN 2345-0282 (online) http://jssidoi.org/jesi/

2017 Volume 5 Number 2 (December)

http://doi.org/10.9770/jesi.2017.5.2(1)

\begin{tabular}{|c|c|c|c|c|c|c|}
\hline & Operating Margin & $0.32 \%$ & $-1.72 \%$ & $1.54 \%$ & $0.44 \%$ & $-15.30 \%$ \\
\hline & EBT Margin & $0.24 \%$ & $-1.77 \%$ & $1.47 \%$ & $0.37 \%$ & $-15.40 \%$ \\
\hline & Net Margin & $0.12 \%$ & $-1.92 \%$ & $1.00 \%$ & $0.03 \%$ & $-15.15 \%$ \\
\hline KCM1R & Revenue & $100.00 \%$ & $100.00 \%$ & $100.00 \%$ & $100.00 \%$ & $100.00 \%$ \\
\hline \multirow[t]{5}{*}{ Kurzemes ciltslietu un mākslīgās apsēklošanas stacija } & Cost of Revenue & $52.87 \%$ & $54.08 \%$ & $54.41 \%$ & $52.98 \%$ & $52.17 \%$ \\
\hline & Gross Margin & $47.13 \%$ & $45.92 \%$ & $45.59 \%$ & $47.02 \%$ & $47.83 \%$ \\
\hline & Operating Margin & $6.07 \%$ & $10.55 \%$ & $-8.81 \%$ & $13.04 \%$ & $12.18 \%$ \\
\hline & EBT Margin & $6.07 \%$ & $10.55 \%$ & $-8.82 \%$ & $12.96 \%$ & $12.18 \%$ \\
\hline & Net Margin & $5.72 \%$ & $10.16 \%$ & $-9.31 \%$ & $11.94 \%$ & $12.18 \%$ \\
\hline BAL1R & Revenue & $100.00 \%$ & $100.00 \%$ & $100.00 \%$ & $100.00 \%$ & $100.00 \%$ \\
\hline \multirow[t]{5}{*}{ Latvijas balzams } & Cost of Revenue & $81.09 \%$ & $79.90 \%$ & $77.34 \%$ & $77.24 \%$ & $77.29 \%$ \\
\hline & Gross Margin & $18.91 \%$ & $20.10 \%$ & $22.66 \%$ & $22.76 \%$ & $22.71 \%$ \\
\hline & Operating Margin & $10.58 \%$ & $10.31 \%$ & $12.98 \%$ & $11.39 \%$ & $12.53 \%$ \\
\hline & EBT Margin & $10.58 \%$ & $10.31 \%$ & $12.98 \%$ & $11.39 \%$ & $12.53 \%$ \\
\hline & Net Margin & $8.85 \%$ & $8.85 \%$ & $10.90 \%$ & $9.58 \%$ & $9.92 \%$ \\
\hline GZE1R & Revenue & $100.00 \%$ & $100.00 \%$ & $100.00 \%$ & $100.00 \%$ & $100.00 \%$ \\
\hline \multirow[t]{5}{*}{ Latvijas Gāze } & Cost of Revenue & $92.34 \%$ & $90.61 \%$ & $89.91 \%$ & $75.23 \%$ & $78.90 \%$ \\
\hline & Gross Margin & $7.66 \%$ & $9.39 \%$ & $10.09 \%$ & $24.77 \%$ & $21.10 \%$ \\
\hline & Operating Margin & $5.72 \%$ & $6.07 \%$ & $6.99 \%$ & $7.80 \%$ & $11.03 \%$ \\
\hline & EBT Margin & $5.79 \%$ & $6.09 \%$ & $7.02 \%$ & $7.82 \%$ & $11.04 \%$ \\
\hline & Net Margin & $4.96 \%$ & $5.13 \%$ & $5.98 \%$ & $6.86 \%$ & $10.91 \%$ \\
\hline LJM1R & Revenue & $100.00 \%$ & $100.00 \%$ & $100.00 \%$ & $100.00 \%$ & $100.00 \%$ \\
\hline \multirow[t]{5}{*}{ Latvijas Jūras medicīnas centrs } & Cost of Revenue & $95.24 \%$ & $100.20 \%$ & $92.77 \%$ & $96.12 \%$ & $94.04 \%$ \\
\hline & Gross Margin & $4.76 \%$ & $-0.20 \%$ & $7.23 \%$ & $3.88 \%$ & $5.96 \%$ \\
\hline & Operating Margin & $-1.48 \%$ & $-6.49 \%$ & $18.72 \%$ & $-12.79 \%$ & $1.82 \%$ \\
\hline & EBT Margin & $-1.48 \%$ & $-6.49 \%$ & $18.72 \%$ & $-12.79 \%$ & $1.83 \%$ \\
\hline & Net Margin & $-1.80 \%$ & $-6.19 \%$ & $18.72 \%$ & $-6.48 \%$ & $-1.63 \%$ \\
\hline SMA1R & Revenue & $100.00 \%$ & $100.00 \%$ & $100.00 \%$ & $100.00 \%$ & $100.00 \%$ \\
\hline \multirow[t]{5}{*}{ PATA Saldus } & Cost of Revenue & $90.83 \%$ & $99.40 \%$ & $96.30 \%$ & $101.44 \%$ & $96.15 \%$ \\
\hline & Gross Margin & $9.17 \%$ & $0.60 \%$ & $3.70 \%$ & $-1.44 \%$ & $3.85 \%$ \\
\hline & Operating Margin & $5.24 \%$ & $-1.10 \%$ & $1.99 \%$ & $-3.21 \%$ & $2.43 \%$ \\
\hline & EBT Margin & $4.82 \%$ & $-1.10 \%$ & $1.05 \%$ & $-4.63 \%$ & $1.40 \%$ \\
\hline & Net Margin & $4.00 \%$ & $-1.15 \%$ & $1.01 \%$ & $-4.74 \%$ & $2.27 \%$ \\
\hline
\end{tabular}


The International Journal

ENTREPRENEURSHIP AND SUSTAINABILITY ISSUES

ISSN 2345-0282 (online) http://jssidoi.org/jesi/

2017 Volume 5 Number 2 (December)

http://doi.org/10.9770/jesi.2017.5.2(1)

\begin{tabular}{|c|c|c|c|c|c|c|}
\hline RAR1R & Revenue & $100.00 \%$ & $100.00 \%$ & $100.00 \%$ & $100.00 \%$ & $100.00 \%$ \\
\hline \multirow[t]{5}{*}{ Rīgas autoelektroaparātu rūpnīca } & Cost of Revenue & $129.67 \%$ & $104.16 \%$ & $134.24 \%$ & $125.34 \%$ & $653.91 \%$ \\
\hline & Gross Margin & $-29.67 \%$ & $-4.16 \%$ & $-34.24 \%$ & $-25.34 \%$ & $-553.91 \%$ \\
\hline & Operating Margin & $11.30 \%$ & $77.87 \%$ & $-40.30 \%$ & $15.50 \%$ & $-565.84 \%$ \\
\hline & EBT Margin & $12.07 \%$ & $77.87 \%$ & $-40.30 \%$ & $15.50 \%$ & $-565.84 \%$ \\
\hline & Net Margin & $1.32 \%$ & $71.67 \%$ & $-46.12 \%$ & $8.42 \%$ & $-565.84 \%$ \\
\hline RER1R & Revenue & $100.00 \%$ & $100.00 \%$ & $100.00 \%$ & $100.00 \%$ & $100.00 \%$ \\
\hline \multirow[t]{5}{*}{ Rīgas elektromašīnbūves rūpnīca } & Cost of Revenue & $73.78 \%$ & $76.22 \%$ & $84.48 \%$ & $95.05 \%$ & $84.48 \%$ \\
\hline & Gross Margin & $26.22 \%$ & $23.78 \%$ & $15.52 \%$ & $4.95 \%$ & $15.52 \%$ \\
\hline & Operating Margin & $16.87 \%$ & $11.46 \%$ & $2.52 \%$ & $0.76 \%$ & $2.40 \%$ \\
\hline & EBT Margin & $16.87 \%$ & $11.46 \%$ & $2.52 \%$ & $0.76 \%$ & $2.04 \%$ \\
\hline & Net Margin & $16.24 \%$ & $9.82 \%$ & $1.95 \%$ & $-1.25 \%$ & $1.64 \%$ \\
\hline RJR1R & Revenue & $100.00 \%$ & $100.00 \%$ & $100.00 \%$ & $100.00 \%$ & $100.00 \%$ \\
\hline \multirow[t]{5}{*}{ Rīgas juvelierizstrādājumu rūpnīca } & Cost of Revenue & $43.48 \%$ & $63.66 \%$ & $76.60 \%$ & $70.65 \%$ & $70.80 \%$ \\
\hline & Gross Margin & $56.52 \%$ & $36.34 \%$ & $23.40 \%$ & $29.35 \%$ & $29.20 \%$ \\
\hline & Operating Margin & $19.89 \%$ & $5.69 \%$ & $-25.33 \%$ & $-0.93 \%$ & $-2.81 \%$ \\
\hline & EBT Margin & $19.89 \%$ & $5.69 \%$ & $-25.33 \%$ & $-0.93 \%$ & $-2.81 \%$ \\
\hline & Net Margin & $18.97 \%$ & $4.22 \%$ & $-23.31 \%$ & $-1.46 \%$ & $-2.81 \%$ \\
\hline RKB1R & Revenue & $100.00 \%$ & $100.00 \%$ & $100.00 \%$ & $100.00 \%$ & $100.00 \%$ \\
\hline \multirow[t]{5}{*}{ Rīgas kuğu būvētava } & Cost of Revenue & $101.61 \%$ & $99.95 \%$ & $99.64 \%$ & $91.38 \%$ & $95.28 \%$ \\
\hline & Gross Margin & $-1.61 \%$ & $0.05 \%$ & $0.36 \%$ & $8.62 \%$ & $4.72 \%$ \\
\hline & Operating Margin & $0.28 \%$ & $-1.12 \%$ & $-4.51 \%$ & $4.59 \%$ & $1.31 \%$ \\
\hline & EBT Margin & $0.20 \%$ & $-1.12 \%$ & $-4.51 \%$ & $4.59 \%$ & $1.31 \%$ \\
\hline & Net Margin & $0.08 \%$ & $-1.28 \%$ & $-6.08 \%$ & $1.04 \%$ & $0.82 \%$ \\
\hline SCM1R & Revenue & $100.00 \%$ & $100.00 \%$ & $100.00 \%$ & $100.00 \%$ & $100.00 \%$ \\
\hline \multirow[t]{5}{*}{ Siguldas ciltslietu un mākslīgās apsēklošanas stacija } & Cost of Revenue & $41.97 \%$ & $42.52 \%$ & $39.06 \%$ & $40.14 \%$ & $43.35 \%$ \\
\hline & Gross Margin & $58.03 \%$ & $57.48 \%$ & $60.94 \%$ & $59.86 \%$ & $56.65 \%$ \\
\hline & Operating Margin & $11.19 \%$ & $8.02 \%$ & $15.94 \%$ & $8.73 \%$ & $9.58 \%$ \\
\hline & EBT Margin & $8.99 \%$ & $8.02 \%$ & $15.94 \%$ & $8.73 \%$ & $9.58 \%$ \\
\hline & Net Margin & $7.42 \%$ & $6.45 \%$ & $13.58 \%$ & $6.85 \%$ & $7.97 \%$ \\
\hline TKB1R & Revenue & $100.00 \%$ & $100.00 \%$ & $100.00 \%$ & $100.00 \%$ & $100.00 \%$ \\
\hline \multirow[t]{2}{*}{ Tosmares kugúbūvētava } & Cost of Revenue & $92.58 \%$ & $97.56 \%$ & $101.96 \%$ & $83.18 \%$ & $90.16 \%$ \\
\hline & Gross Margin & $7.42 \%$ & $2.44 \%$ & $-1.96 \%$ & $16.82 \%$ & $9.84 \%$ \\
\hline
\end{tabular}


ENTREPRENEURSHIP AND SUSTAINABILITY ISSUES

ISSN 2345-0282 (online) http://jssidoi.org/jesi/

2017 Volume 5 Number 2 (December)

http://doi.org/10.9770/jesi.2017.5.2(1)

\begin{tabular}{|c|c|c|c|c|c|c|}
\hline & Operating Margin & $1.31 \%$ & $-0.40 \%$ & $-6.59 \%$ & $4.30 \%$ & $1.35 \%$ \\
\hline & EBT Margin & $0.21 \%$ & $-0.40 \%$ & $-6.59 \%$ & $4.30 \%$ & $1.35 \%$ \\
\hline & Net Margin & $-0.54 \%$ & $-1.49 \%$ & $-8.21 \%$ & $2.37 \%$ & $0.43 \%$ \\
\hline VSS1R & Revenue & $100.00 \%$ & $100.00 \%$ & $100.00 \%$ & $100.00 \%$ & $100.00 \%$ \\
\hline \multirow[t]{5}{*}{ Valmieras stikla šķiedra } & Cost of Revenue & $52.76 \%$ & $54.21 \%$ & $52.60 \%$ & $49.44 \%$ & $53.93 \%$ \\
\hline & Gross Margin & $47.44 \%$ & $45.94 \%$ & $47.40 \%$ & $50.56 \%$ & $46.07 \%$ \\
\hline & Operating Margin & $8.15 \%$ & $5.91 \%$ & $8.00 \%$ & $5.65 \%$ & $5.82 \%$ \\
\hline & EBT Margin & $5.74 \%$ & $5.91 \%$ & $7.19 \%$ & $4.95 \%$ & $5.12 \%$ \\
\hline & Net Margin & $5.51 \%$ & $5.77 \%$ & $6.98 \%$ & $4.52 \%$ & $3.85 \%$ \\
\hline VEF1R & Revenue & $100.00 \%$ & $100.00 \%$ & $100.00 \%$ & $100.00 \%$ & $100.00 \%$ \\
\hline \multirow[t]{5}{*}{ VEF } & Cost of Revenue & $71.26 \%$ & $72.38 \%$ & $73.08 \%$ & $70.44 \%$ & $68.63 \%$ \\
\hline & Gross Margin & $28.74 \%$ & $27.62 \%$ & $26.92 \%$ & $29.56 \%$ & $31.37 \%$ \\
\hline & Operating Margin & $20.98 \%$ & $6.74 \%$ & $4.62 \%$ & $8.01 \%$ & $23.50 \%$ \\
\hline & EBT Margin & $6.64 \%$ & $6.74 \%$ & $4.62 \%$ & $8.01 \%$ & $23.50 \%$ \\
\hline & Net Margin & $2.92 \%$ & $0.13 \%$ & $-0.30 \%$ & $3.08 \%$ & $23.50 \%$ \\
\hline RRR1R & Revenue & $100.00 \%$ & $100.00 \%$ & $100.00 \%$ & $100.00 \%$ & $100.00 \%$ \\
\hline \multirow[t]{5}{*}{ VEF Radiotehnika RRR } & Cost of Revenue & $97.48 \%$ & $119.97 \%$ & $124.41 \%$ & $125.82 \%$ & $110.70 \%$ \\
\hline & Gross Margin & $2.52 \%$ & $-19.97 \%$ & $-24.41 \%$ & $-25.82 \%$ & $-10.70 \%$ \\
\hline & Operating Margin & $-3.93 \%$ & $-20.18 \%$ & $-73.08 \%$ & $57.43 \%$ & $-88.18 \%$ \\
\hline & EBT Margin & $-10.79 \%$ & $-20.18 \%$ & $-73.08 \%$ & $57.43 \%$ & $-88.18 \%$ \\
\hline & Net Margin & $-17.61 \%$ & $-27.48 \%$ & $-81.92 \%$ & $48.45 \%$ & $-90.36 \%$ \\
\hline
\end{tabular}

Considering these data, it is possible to make certain conclusions about financial health of Latvian stock companies.

\section{Conclusions}

1. Gross Margin increased from 2012 until 2016 for 7 Latvian stock companies of 24: KCM1R (47.13\% 47.83\%), BAL1R (18.91\% - 22.71\%), GZE1R (7.66\% - 21.10\%), LJM1R (4.76\% - 5.96\%), RKB1R (-1.61\% $-4.72 \%)$, TKB1R $(7.42 \%-9.84 \%)$, VEF1R $(28.74 \%-31.37 \%)$.

2. Gross Margin decreased from 2012 until 2016 for 17 Latvian stock companies of 24: GR1R (61.76\% 54.65\%), HMX1R (27.04\% - 13.39\%), LSC1R (20.54\% - 14.9\%), OLF1R (78.37\% - 63.09\%), SAF1R (44.07\% - 30.04\%), BRV1R (13.43\% - 6.99\%), LOK1R (15.28\% - ( -10.54\%)), DPK1R (19.9\% - 1.25\%), GRZ1R (35.37\% - (-106.75\%)), KA11R (9.43\% - (-6.87\%)), SMA1R (9.17\% - 3.85\%), RAR1R (-29.67\% - ($553.91 \%)$ ), RER1R (26.22\% - 15,52\%), RJR1R (56.52\% - 29.20\%), SCM1R (58.03\% - 56.65\%), VSS1R $(47.44 \%-46.07 \%)$, RRR1R $(2.52 \%-(-10.70 \%))$.

3. Gross Margin is negative for 5 Latvian stock companies of 24: LOK1R (-10.54\%), GZR1R (-106.75\%), KA11R (-6.87\%), RAR1R (-554\%), RRR1R (-10.7\%). 
ENTREPRENEURSHIP AND SUSTAINABILITY ISSUES

ISSN 2345-0282 (online) http://jssidoi.org/jesi/

2017 Volume 5 Number 2 (December)

http://doi.org/10.9770/jesi.2017.5.2(1)

4. Operating Margin is less than 5\% for 16 Latvian stock companies of 24: HMX1R (4.62\%), LSC1R (14.99\%), SAF1R (4.61\%), BRV1R (-12.24\%), LOK1R (-21.21\%), DPK1R(1.25\%), GRZ1R (-106.75\%), KA11R (-6.87\%), LJM1R (1.82\%), SMA1R (2.43\%), RAR1R (-565.84\%), RER1R(2.4\%), RJR1R (-2.81\%), RKB1R (1.31\%), TKB1R(1.35\%), RRR1R (-88.18\%).

5. According to the condition of their financial health, Latvian stock companies can be divided on the three approximately equal groups. For approximately third part of Latvian stock companies financial health was improved during last 5 years and can be evaluated at present time as good. For the next third part the financial health remained approximately at the same level and can be evaluated as average. For the remaining third part of Latvian stock companies the financial health became worse during last 5 years and at present time can be evaluated as problematic.

6. The situation in Latvia in general corresponds to situation in European countries, where the amounts of companies who are "going up", "going down" and "are stable" on 5 years time interval are approximately equal. There are variations between different countries, of course, but in general, situation in Latvia is similar to situation in majority of European countries. In the USA situation is different, but this is the subject for special consideration.

\section{References}

Belás, J.; Mišanková, M.; Schönfeld, J.; Gavurova, B. 2017. Credit risk management: financial safety and sustainability aspects, Journal of Security and Sustainability Issues 7(1): 79-93. https://doi.org/10.9770/jssi.2017.7.1(7)

Chung, S.; Rosenberg, M.; Tomeo, J.F. 2004. Hedge Fund of Fund Allocations Using a Convergent and Divergent Strategy Approach, The Journal of Alternative Investments 7(1): 44-53. http://www.turtletrader.com/pdfs/convergent.pdf

Debreceny, R.; d'Eri, A.; Felden, C.; Farewell, S. 2010. Feeding the Information Value Chain: Deriving Analytical Ratios from XBRL filings to the SEC http://citeseerx.ist.psu.edu/viewdoc/download?doi=10.1.1.453.2558\&rep=rep1\&type=pdf

Fernandez, P. 2002. Company Valuation Methods. The most common errors in valuations, Working paper no 449 of IESE Business Schol-University Navarra http://www.iese.edu/research/pdfs/di-0449-e.pdf

Graham, B. 1934. Security Analysis. The classic 1934 edition, Mcgraw-Hill Book Company, Inc., New York, London, 701 p.

Hill C.W.L.; Jones G.R. 2013. Strategic Management. An Integrated Approach, Cengage Learning, 416 p.

Kampgen, B.; Weller, T.; O’Riain, S.; Weber, C.; Harth, A. 2014. Accepting the XBRL Challenge with Linked Data for Financial Data Integration, Institute AIFB, Karlsruhe Institute of Technology, Karlsruhe, Germany https://link.springer.com/chapter/10.1007/978-3-319-07443-6_40

Koller, T.; Goedhart, M.; Wessels. 2010. Valuation: Measuring and Managing the Value of Companies, University Edition Fourth Edition, McKinsey\&Company, 768 p.

Lev, B.; Thiagarajan, S.R. 1993. Fundamental Information Analysis, Journal of Accounting Research 31:190-215 http://doi.org/10.2307/2491270

Ou, J.A.; Penmann, S.H. 1989. Financial statement analysis and the prediction of stock returns, Journal of Accounting and Economics 11: 295-330 https://EconPapers.repec.org/RePEc:eee:jaecon:v:11:y:1989:i:4:p:295-329

Owen, D.; Griffiths, R. 2006. Mapping the Markets. A guide to stockmarket analysis, The Economist, 134 p.

Paseková, M.; Svitaková, B.; Kramá, E.; Otrusinová, M. 2017. Towards financial sustainability of companies: issues related to reporting errors, Journal of Security and Sustainability Issues 7(1): 141-153. https://doi.org/10.9770/jssi.2017.7.1(12) 
ENTREPRENEURSHIP AND SUSTAINABILITY ISSUES

ISSN 2345-0282 (online) http://jssidoi.org/jesi/

2017 Volume 5 Number 2 (December)

http://doi.org/10.9770/jesi.2017.5.2(1)

Websites (accessed: September 2017):

Financial Vizualizations FINVIZ www.finviz.com

Google Finance https://www.google.com/finance/

Yahoo Finance http://finance.yahoo.com/

U.S. Security and Exchange Commision homepage www.sec.gov

https://www.oldschoolvalue.com/blog/valuation-methods/balance-sheet-ratios/

Galina Hilkevica is the Professor of Information Technologies Faculty (ITF) of Ventspils University College (VUC), Latvia. She is former Dean of ITF, director of IT programme, Member Latvian Mathematical Society board. Research interests: applied mathematics, optimization methods, financial mathematics, investment theory and applications.

ORCID ID: orcid.org/0000-0003-0312-3578

Sergejs Hilkevics is the Professor of Faculty of Economics and Business Administration of Ventspils University College (VUC), Latvia. He is former Vice-Rector in Research and Development of VUC, director of MBA and doctoral programmes, Member of Professor Council. Research interests: business administration, financial analysis, investment theory and applications.

ORCID ID: orcid.org/0000-0002-9667-3730

Register for an ORCID ID

https://orcid.org/register

Copyright (C) 2017 by author(s) and VsI Entrepreneurship and Sustainability Center

This work is licensed under the Creative Commons Attribution International License (CC BY).

http://creativecommons.org/licenses/by/4.0/

c) (†) Open Access 